\title{
FASTING IN COUNTRIES WHERE THE DAY IS VERY LONG OR VERY SHORT: A Study of Muslims in the Netherlands ${ }^{1}$
}

\author{
Ahmad Najib Burhani \\ The Indonesian Institute of Sciences (LIPI), Jakarta, Indonesia
}

\begin{abstract}
Ramadan falls both during winter and autumn months, when the days are cool and short, and spring and summer months, when the days are long and hot. Fasting in areas where the climate is extremely hot and the day is more than twenty hours is a double hardship that can be a dangerous assault on physical condition. In contrast to that, fasting in areas where the day is very short is, to some extent, like an interval between breakfast and lunch or between lunch and dinner. This article, therefore, intends to discover how Muslims in the countries where the day is either very long or very short deal with the problem of the fasting time. This research is based on the practices of some Muslims in the Netherlands with a variety of countries of origin. This article attempts to answer the following questions: How did they manage their fasting time in the summer or when the day is very long? How did they manage their fasting time in the winter or when the day is very short? What kind of fiqh book or fatwa did they use as reference? Did they think that fasting obligation was dangerous for their health when the day was very long?
\end{abstract}

[Bulan Ramadan bisa tiba pada musim dingin dan musim gugur, ketika siang hari pendek dan sejuk, tapi Ramadan juga bisa tiba pada musim semi dan musim panas, ketika siang hari sangat panjang dan panas. Puasa

${ }^{1}$ This article is originally a research paper submitted for the seminar on Problems and Methods of Islamic Studies: The Empirical Study of Islam in Contemporary Western Europe under the supervision of Professor P.S. van Konigsveld at Leiden University in 2004. 
di tempat yang sangat panas dan dengan panjang siang hari lebih dari dua pulub jam adalah beban yang berat dan bisa berbahaya bagi kondisi fisik pelakunya. Sebaliknya, puasa di tempat yang siang harinya sangat pendek terasa tak seperti puasa karena ia hanya seperti interval antara makan pagi dan makan siang atau antara makan siang dan makan malam. Tulisan ini didasarkan pada penelitian terbadap praktik berpuasa orang-orang Islam di Belanda dari berbagai negara asal. Pertanyaan yang ingin dijawab dalam tulisan ini adalah: Bagaimana umat Islam Belanda melaksanakan puasa pada musim panas atau ketika siang hari teramat panjang? Bagaimana pula mereka menjalankan puasa pada musim gugur atau ketika siang hari sangat pendek? Buku fikih apa atau fatwa dari siapa yang mereka pakai sebagai dasar praktik ibadah puasa itu? Apakah mereka berpikir bahwa praktik puasa di musim yang siang harinya sangat panjang akan berbahaya bagi kesehatan mereka?

Keywords: Fatwā, fasting session, Ramadan, Islam in Europe

DOI: 10.14421 /ajis.2013.511.159-188

\section{A. Introduction}

Ramadan can arrive at any season throughout a Muslim's lifetime. ${ }^{2}$ Every daylight period of the year is of different length in different locations on the face of the earth, except for the spring and autumn equinoxes. ${ }^{3}$ Ramadan will fall both during winter and autumn months, when the days are cool and short, and spring and summer months, when

2 Ramadan is the ninth month of the Islamic lunar calendar (bijriyya). A lunar month is approximately 29.5 days, which is the time it takes the moon to orbit the earth. Because a lunar month is on average one day shorter than a solar month, a lunar year is about 11 days shorter than a solar year or the Gregorian calendar. Therefore, the month of Ramadan comes about 11 days earlier each year. The season in which Ramadan is celebrated changes slowly over a 33-year cycle.

3 The shape of the earth is not flat but round elliptical. This means that the countries on its surface do not have the same length of daylight and night hours. The position of their longitude and latitude determines how long or how short the hours of sunshine they will receive. The polar countries, both at the North and the South Pole, have the day lasts for roughly a half-year and the night for the other half. The countries near the Poles have enormous difference in daylight and night hours in every season. 
the days are long and hot. ${ }^{4}$ At a certain time, Ramadan will occur during the winter in the northern hemisphere, but in the southern hemisphere it is summer. After the passage of several years, this situation will reverse itself and Ramadan will occur during the summer in the northern hemisphere and the winter in the southern hemisphere. ${ }^{5}$

Fasting is probably much easier to observe when daytime is at its shortest. Moreover, the prohibition even on consumption of water during daytime hours is more tolerable when the daytime temperatures are in the mid-60s rather than approaching 100 degrees. ${ }^{6}$ Fasting is a compulsory for all Muslims. Fasting is a sort of hardship obligation. Fasting in areas where the climate is extremely hot and the day is more than 20 hours is a double hardship. When it is observed, it is a dangerous assault on their physical condition. In contrast to that, fasting in areas where the day is very short is, to some extent, like an interval between breakfast and lunch or between lunch and dinner. Since there are some Muslims living under such conditions it would seem to be useful to investigate the issue of fasting in such conditions.

This article intends to discover how Muslims in the countries where the day is either very long or very short deal with the problem of the fasting time and what kind of fatwa they use to deal with this problem. In short, this study attempts to answer the following questions: How did they manage their fasting time in the summer or when the day is very long? How did they manage their fasting time in the winter or when the day is very short? What kind of fiqh book or fatwa did they use as reference? Did they think that fasting obligation was dangerous for their health when the day was very long? This research was based on the practices of some Muslims in the Netherlands with a variety of countries

${ }^{4}$ K. Wagtendonk, Fasting in The Koran (Leiden: E.J. Brill, 1968), p. 1 note 2; Sachiko Murata and William C. Chittick, The Vision of Islam (New York: Paragon House, 1994), p. 17; See also "The Star and Crescent," compiled by Al-Islaah Publications from Sources: islamicvoice; islam.about; ameen/crescent, courtesy: www.everymuslim.com. See in http:/ / zikr.org/fast/star.htm and "Seyaam Ramadan (The Fasting of Ramadan)" in http://www.quran-islam.org/167.html. Accessed 15 June 2003.

${ }^{5}$ Mir Javid Jalali, "Ramadan is a Time of Fasting and Spirituality" in http:// www.irvineworldnews.com/Astories/dec7/ramadan.html. Accessed 15 June 2003

${ }^{6}$ Douglas Jehl, "In Egypt this Winter, Fasting for Faith is a Long Banquet," broadcast on BICNews 24 January 1998. See in http://www.iol.ie/ afifi/BICNews/ Islam/islam33.htm. Accessed 15 June 2003. 
of origin by interviewing some pious Muslims and some imäms in Leiden and The Hague. In addition to that, I also interviewed ordinary people in those two places. There is no discrepancy in the behaviour of imams and the ordinary people in this context. The total respondents of this study are 13 persons.

Apart from that, this article also intends to ask the respondents about the hermeneutical problem of some Qur'anic verses related to the obligation of fasting. The Qur'an outlines the fasting hours in the following verse: "and eat and drink, until the white streak of dawn appear to you distinct from the blackness of night; then complete your fast till the night appears" 2:187. What are the meaning of the nahär (day) and the layl (night)? When does the night actually start? Does it start at sunset or does the night start when all light has disappeared from the sky? Or, does the nighttime start at around five or six o'clock in the evening? In the connection with hermeneutical problem, it seemed pertinent to ask people what is the meaning of fasting verse "Allah intends every facility for you; He does not want to put you to difficulties" (2:185)? Is fasting in the summer a sort of hardship? Is it not an inconvenience to begin the fasting period at different times during a year? Probably, it would be apposite to ask or connect the practice of fasting in the summer with the practice of wisal (continuous fasting of day and night) that was declared strictly forbidden by the Prophet.

This article begins with an introduction. It attempts to describe the background and the significance, scope, review of related studies, sources, method, and systematic process of the work. The next part will discuss the normative or theoretical background to the study. The normative sources of fasting will be discussed. The following part is a discussion about the findings in the research. Then, it attempts to compare between normative sources and the real problems of social life, to assess whether Islamic normative sources match or correspond to the problem in regions with four seasons in the case of fasting.

\section{B. The Fasting Month of Ramadan}

Ramadan is a special month for Muslims around the world. It is the holy month, the month in which the Qur'an was revealed to the Prophet Muhammad. It is not a New Year, but celebrated like a New 
Year. ${ }^{7}$ Ramadan is a time of worship or devotion to God, self-discipline, austerity and giving charity. Ramadan is also a time for reflection, religious study, reading the Qur'an, purifying one's behaviour, and doing good deeds. In many ways, the month of Ramadan serves as a kind of tuneup for the spiritual lives, to enhance spirituality.

There are many intentions bound up with fasting in Ramadan such as a great exercise in self-control and the development of will power. Through the experiencing of hunger, fasting is a means to develop sympathy for the less fortunate, to feel more compassion with more sincerity for the plight of poor people worldwide who are suffering, and consequently learning to be more charitable and more thankful for and appreciative of God's bounties. Fasting is also beneficial to the health and provides a break in the cycle of rigid habits and over indulgence. However, the most important intention of fasting in Ramadan, as mentioned in the Qur'an 2: 183, is taqwa (self-restraint).

Fasting Ramadan is a calendrical rite for Muslims. It is intended as a process of social transformation or as a catharsis. Following Arnold van Gennep's ideas on rites de passage (rites of passage), as a kind of ritual fasting Ramadan has a threefold structure: separation à transition à incorporation or reaggregation. ${ }^{8}$ In Ramadan, Muslims find themselves in a condition of separation from their previous one. After fasting, they are reborn in a transformed condition. Fasting in Ramadan is a kind of liminality for the life of Muslims. For the survival of Islam itself, the succession of Islamic teachings from one generation to another has most probably been facilitated by means of ritual like fasting in Ramadan. Without preserving rituals, a certain culture or tradition will be driven to the brink of extinction.

\section{Fasting Ramadan: Definition and Origin}

The Arabic word for fasting is sawm, from the root $s-w-m$. Siyam is the infinitive (masdar) word from sawm. The meaning of siyam is "to be

${ }^{7}$ According to Humphreys, this sort of calendar was established in the reign of the Caliph 'Umar. See R. Stephen Humphreys, Islamic History: A Framework for Inquiry (London: I.B. Tauris, 1991), p. 19.

${ }^{8}$ Fiona Bowie, The Anthropology of Religion (Oxford: Blackwell, 2001), pp. 151-83. 
at rest" (imsäk). ${ }^{9}$ This word is used in the Qur'an (2:187) with reference to abstention from eating and drinking: “... and eat and drink, until the white streak of dawn appear to you distinct from the blackness of night; then complete your fast till the night appears..." Besides abstention from eating and drinking, the word Șawm is also used in the Qur'an (19:26) to indicate an abstention from talking: "So eat and drink and cool (thine) eye. And if thou dost see any human, say, 'I have vowed a fast (sawm) to (Allah) Most Gracious, and this day will I enter into no talk with any human being." 10

The technical meaning of the siyam is abstinence (imsäk) from things which break the fast --i.e. food, drink, and sexual intercourse from dawn until sunset-- with the intention (niyya) of doing so (for the sake of Allah). ${ }^{11}$ The dawn is the time when someone can see natural light on the eastern horizon. That natural light is sufficiently bright to differentiate a black piece of string from a white piece of string which happens around an hour and a half before sunrise. ${ }^{12}$

Ramadan is the name of the ninth month of the Islamic lunar calendar. In this calendar, each year consist of twelve months starting with Muharram. The root of the word Ramadan is $r-m-d$. It means the month of scorching, and is thus a reference to the idea that the fast scorches away human sins. Others argue that it simply means high summer or extreme heat. Ramadan was named so because in the ancient Arab Ramadan always fell in the summer. Before the coming of Islam, the ancient Arab did not use a purely lunar calendar, but they used lunar-solar

9 Al-Sayyid Sābiq, Fiqh al-Sunnah, Juz I (Cairo: Dār al-Fath li al-a 'ām al-'Arabī, 1997), p. 319; C.C. Berg (ed.), "Șawm," in The Encyclopaedia of Islam, WebCDedition, Brill Academic Publishers, 2003.

${ }_{10}$ Wahbah al-Zuhailī, al-Figh al-Islāmì wa Adillatubū, Juz II (Damascus: Dār al-Fikr, 1996), p. 566; Säbiq, Fiqh al-Sunnah, p. 319; "Seyaam Ramadan (The Fasting of Ramadan)".

11 Al-Zuhailī, al-Fiqh al-Islāmî, p. 566; Sābiq, Fiqh al-Sunnah, p. 320; C.C. Berg (ed.), "Ṣawm”; Yusuf al-Qaradawi, Fiqh al-Siyām, Dār al-Sahwah \& Dār al-Wafä', Cairo and Mansurah (Egypt), 1991, pp. 9-10 and Muslim, Sahīh Muslim, Kitab al-Ṣawm, vol. 2, trans. by 'Abdul Hamid Siddiq (Kashmir, Lahore: Sh. Muhammad Ashraf, 1973), p. 522, cited by Mohamed Ali Mohamed Abou Sheishaa, "Muslims' Celebration of the Month of Ramadan in the Netherlands," a paper submitted to the seminar The Empirical Study of Islam in Contemporary Western Europe, Leiden University, 2001, p. 6.

12 Sachiko Murata and William C. Chittick, The Vision of Islam, pp. 17-9. 
calendar by adding intercalary months, with an extra thirteenth month every three years in perpetuity, similar to the Jewish calendar. In that kind of system, the lunar months fall within the same season every year and Ramadan always fell in summer. ${ }^{13}$

The fast of Ramadan did not become a religious obligation for Muslims until the year AD 623. It was instituted by the revelation of Sura 2: 179-81. These verses announced the abolition of the fast of the 'Ashürā', the 10th day of the month of Muharram, as an obligation for the Muslims. The fast of the 'Ashürā' was also practiced at that time by Jews as a commemoration of the Day of Atonement (the revelation of the law to Moses). From this point, some scholars, such as C.C. Berg, G. Von Grunebaum, and K. Wagtendonk, accused that the origin of fasting Ramadan was in imitation of the Jewish tradition. ${ }^{14}$ In this article, I do not attempt to delve deeply into the origin of fasting Ramadan. I only want to show that fasting was prescribed by God to Muhammad and the Muslims as a religious obligation. This kind of obligation was also prescribed to the people before the coming of Islam. "O ye who believe! Fasting is prescribed to you as it was prescribed to those before you, that ye may (learn) self-restraint" (Q. 2:183).

\section{Fasting Ramadan: The Fourth Pillar of Islam}

The fast of Ramadan is the fourth of the five pillars or foundations of Islam. It is a religious obligation and one of the most important rituals for every Muslims. The obligation of this ritual is clearly stated in the Qur'an 2: 183-185. Fasting in Ramadan is obligatory for all Muslims who are mentally and physically fit, past the age of puberty, in a settled situation (not travelling), and are sure that fasting is unlikely to cause real physical or mental injury. The following are exempted from fasting

${ }^{13}$ By adding a third month from time to time, the link between the name of months and the seasons does not break. The Jews still preserve this system. See Wagtendonk, Fasting in the Koran, pp. 123-7; M. Plessner, "Ramadan," in The Encyclopaedia of Islam webCDedition; D. Pingree, "al-Kamar," in EI webCDedition; Syed Akbar Ali, "Observations of Fasting in Nature," in http:/ / www.free-minds.org/ articles/science/ramadhan.htm, and "Ramadan," in http:/ / atheism.about.com/library/ FAQs/islam/blfaq_islam_ramadan.htm. Accessed 3 November 2003.

14 Wagtendonk, Fasting in the Koran, p. 41-46; Plesser, "Ramadan"; C.C. Berg (ed.), "Ṣawm." 
during Ramadan: Children under the age of puberty, the sick, seniors for whom the fast causes unbearable hardships, pregnant women for whom fasting is harmful to self or to the foetus, nursing mothers who fear that fasting causes difficulties for the self or the child she nurses, menstruating women, travellers on journeys and those who are mentally incapacitated or not responsible for their actions. Those who are ill or travelling may substitute the same number of other days. God wishes for you convenience, not hardship. ${ }^{15}$

The hours decreed for fasting are outlined in the Qur'an in the verses mentioned mean that the fasting person may eat and drink until the white thread of light becomes distinguishable from the dark thread of night at dawn. Then, s/he shall fast until the layl (night). From these verses, abstaining from things which break the fast such as food and drink should start at the first thread of light at dawn (between an hour and 2 hours before sunrise), and maintained until night.

The beginning of fasting in Ramadan occurs when the new moon is witnessed. The fast of Ramadan starts on the first dawn after the new month has started. The ending of the fasting is determined by the first visibility of the lunar crescent after conjunction (ru'ya al-bilā). If this occurs before sunset, fasting is maintained until sunset. If the new moon occurs after sunset, the fasting of the month is thus complete and on no more days should it be fasted. After fasting in Ramadan, Muslims will celebrate the festival of breaking the fast, the so-called $\overline{\mathrm{T}} \mathrm{d}$ al-Fitr or al-'İd al-Ṣaghìr on the first of Shawwal.

\section{Fatwa as on Fasting When the Day is Very Long or Very Short}

Fasting in the countries where the days are very long or very short presents some problems. In the Northern Europe, for instance, the duration of fasting in the summer reaches nineteen hours and may sometimes increase to twenty or more in a day. While in the winter, the daylight hours may less than eight hours in a day. A similar problem is also arising in the context of fasting in the midnight sun countries with their nightless days for a half year and dayless nights for the other half.

15 Abd al-Rahman al-Jazāirî, al-Fiqh 'alā al-Madhābib al-'Arba'a (Cairo: Dār al-Kitāb al-'Arabi, n.d.), pp. 456-8; Al-Zuhailî, al-Fiqh al-Islāmî, pp. 610-16; Sābiq, Fiqh al-Sunnah, pp. 325-7. 
This situation means some Muslim minorities living in those parts of the earth raise questions on how they deal with the obligation of fasting in Ramadan.

The presence of Muslims in Europe is most probably as old as the history of Islam. ${ }^{16}$ However, Muslims scholars of the medieval period did not pay serious attention to this kind of issue nor they did not regard this matter as a problem. This fact may due to the fact the presence of Muslims in polar countries and in countries with extreme long and short hours in their days was a very small at that time. According to Mohsen Khalifa, the first fatwa dealing with this problem is the fatwa issued by Sheikh Hasanayn Makhlūf, the former Mufti of Egypt, in 10 June 1952.17 In the time sequence, other fatwa $\bar{a}$ on this problem have been issued by some Islamic scholars such as Maḥmūd Shaltūt, al-'Askarī, Sheikh Jādd al-Haqq 'Alī Jādd al-Haqq, Lajnat al-Fatwa at al-Azhār, the Majalla, 'Abd al-Lațîf Hamza, al-Lajna al-Dā'ima in Saudi Arabi, and Muhammad b. Șălih al-'Uthaymīn. ${ }^{18}$

It is possible to categorize the fatwa $\bar{a}$ issued on the problem of fasting in the countries where the days are very long, we can summarize into the following three groups. First, every Muslim must fast from dawn until sunset. The length of the day is not considered as a Shari i excuse for breaking the fast unless it is proved that such fasting may lead to illness. This is issued by Hasanayn Makhlūf in 1950s. This was representing Dār al-Iftā's view on this problem. Al-'Askarī in 1950s, the Council of Islamic Fiqh Academy in 1982, and Majallat al-Azhar in 1984 have the same opinion as Hasanayn Makhlūf. ${ }^{19}$

Second, calculating the time of fasting according to a nearby country or Mecca and Medina. This is issued by Sheikh Shaltūt in 1950s, Sheikh Jādd al-Haqq 'Alī Jādd al-Haqq in 1980s, Lajnat al-Fatwa al-Azhar in 1983, and 'Abd al-Latị̂f Hamza in 1984. Third, fasting must start from

16 Jorgen S. Nielsen, Towards a European Islam (London: Macmillan Press, 1999), p. 1 .

17 Mohsen Abd al-Aty Haredy Khalifa, "Ramadan Fasting in Northern Europe: A Study of the Fatwa of Sheikh Hasanayn Makhluf and Other Relevant Fatwas and Issues," unpublished paper submitted to the Seminar "Islam and the West: Their Mutual Relations as Reflected in Fatwa Literature," Leiden University, 2000, pp. 1 and 47.

18 Mohsen Khalifa, "Ramadan Fasting in Northern Europe," pp. 15-23.

19 Ibid., pp. 41-2. 
dawn until sunset and the length of the day is not considered as a Shar'i excuse to break the fast. This fatwa also does not take the question of illness into consideration. This was issued by Muhammad b. Ṣălih al'Uthaymīn from Fatāwa al-Lajna al-Dā'ima in Saudi Arabia. ${ }^{20}$

There are two different fatwas concerning the fast in the countries where the days are very short. Firstly, fasting must be performed according to the time in Mecca and Medina or a nearby country. This fatwa is issued by 'Abd al-Majīd Salīm and Sheikh Jādd al-Haqq 'Alī Jādd al-Haqq. Secondly, the Muslims are allowed to fast during the daytime in their country without considering the daylight hours. This is issued by al-Lajna al-Dā'ima. ${ }^{21}$

For fasting in the polar countries with their blending of sunrise and sunset, almost all the scholars share the same fatwa $\bar{a}$. Muslims in the polar countries may calculate the fasting time according to Mecca and Medina, or they may calculate the fasting time according to a nearby country. It is reflected in the fatwās of 'Abd al-Razzāq Muhammad Qinawī, Rashīd Ridā, Yūsuf al-Marsafî, Mustafā al-Shirbīnī, Maḥmūd Shaltūt, and Hasanayn Makhlūf. ${ }^{22}$

\section{Fasting Ramadan in the Netherlands}

Islam is one of the main religions of the Netherlands. According to The Holland Handbook, it is predicted Muslims will be the second largest religion in this country in 2020 and will constitute around 7 per cent of the whole population of the Netherlands. ${ }^{23}$ The facts in the field show growth is faster than this prediction. Statistically, by 1 January 2003 the number of Muslims in the Netherlands was nearly 920,000 or 5.7 per cent of the total population of the Netherlands. The total number of Muslims in this year is 20,000 more than the year before and makes Islam one of the largest religions in the Netherlands. It is 294,000 more than in 1995. In 1995, Muslims constituted 4.1 percent of the total population. Most of the Muslims in the Netherlands are of non-Western descent. They

${ }^{20}$ Ibid., pp. 41-2; See also Al-Zuhailî, al-Fiqh al-Islāmî, pp. 566-7.

${ }^{21}$ Mohsen Khalifa, "Ramadan Fasting in Northern Europe," p. 42.

22 'Abd al-Razzāq Muhammad Qinawî, Fatāwa al-S awm (Cairo: Dar al-Aminn, 1998), p. 15; See also Mohsen Khalifa, "Ramadan Fasting in Northern Europe," p. 42.

${ }^{23}$ Stephanie Dijkstra, The Holland Handbook: The Indispensable Reference Book for the Expatriate, edition 2002-2003 (The Hague: Xpat Media, 2002), p. 144. 
are immigrants from Muslim countries, mainly Turkey (nearly 320,000) and Morocco $(285,000)$, or children of immigrants --constitute 38 per cent of the total number of Muslims. The small number of them is the native Dutch. ${ }^{24}$

\section{Observing Fasting in Ramadan in Very Long or Very Short Days}

In the past half century, according to the conversion tables made by F. Wüstenfeld and E. Mahler, Vergleichungs-Tabellen zur Muslimischen und Iranischen Zeitrechnung (3rd ed., revised by J. Mayr and B. Spuler), Ramadan falls in the summer in the Netherlands in 1916s, 1949s, 1981s, 2013s, and $2046 \mathrm{~s} .{ }^{25}$ The peak of the summer in this country falls in June with the time of dawn at nearly 03.07 a.m. and the time of sun set at around 22.00 at night. ${ }^{26}$ Thus, by following the time of dawn and sunrise, Muslims in this country must do fast in Ramadan around 19 hours in the hot weather of June and the months around June-i.e. May and July. Imām A, the currently head of the board of imams of the Bayt al-Rahmān in Ridderkerk, is one of the Muslims in the Netherlands who has experienced fasting Ramadan in the summer several times. He was born in the Central Moluccas in 1934 and migrated to the Netherlands in 1951.

In my meeting with him, I talked to Imām A about how he managed fasting Ramadan in summer... He said that in 1980s, he must fast in Ramadan around 19 hours. He started fasting at around 03.00 at morning and broke fasting around 10.00 in the evening. To fulfil this obligation he almost killed himself. "I did this as a kind of religious command, I felt myself at death's door (setengah mati). It was severely exhausting." Continuously, he said in order to accomplish this sort of obligation, he spent the whole of his daytime at home severely restricting any physical movement. However, he said that he became accustomed to fasting in

${ }^{24}$ The majority of the population in the Netherlands has no religion. They constitute nearly 40 percent. See Ron Tas, Nearly as Many Muslims as Calvinists in the Netherlands, in www.cbs.nl/en/publications/articles/webmagazine/2003/1298k.htm. Accessed on 10 November 2003.

25 Wüstenfeld, H.F., and E. Mahler, Vergleichungs-Tabellen zur Muslimischen und Iranischen Zeitrechnung Mit Tafeln zur Umrechnung Orient-Christlicher Ären (Wiesbaden: Franz Steiner Verslag GMBH, 1961), pp. 28-31.

${ }^{26}$ Praying time for The Hague in 2003. See www.indah.nl. Accessed in 12 November 2003. 
the long, hot days after several days of performing this obligation. ${ }^{27}$

Imäm A felt that fasting in the summer is very difficult. However, he added an additional commentary that he became accustomed to fasting in the long, hot days. Furthermore, in his following statement, he said that he always added a fasting sunna of six days after ' $\bar{I} \mathrm{~d}$ al-Fitr (festival of the breaking of the Fast). This last commentary seems in contradiction to his previous statement. On the one hand, he said that fasting Ramadan in the summer was severely exhausting, but, on the other hand, he added six extra days fasting after Ramadan.

Imām $\mathrm{C}$ illustrates his personal experience of observing fasting in Ramadan in the summer in the Netherlands with a difference nuance. He was born in 1950 and graduated from Al-Azhār University in Cairo. He came to this country in 1980.

For me, fasting in the summer and in the winter in the Netherlands was much of a muchness. In the summer, when the day was very long, the weather gave people fasting a boast. Thus, there is no particular cause to worry. The only problem that we had to bear was a long time waiting for Maghrib and thirst. In the winter we needed a lot of energy. Hence, although the daytime was short, in the winter we felt hungrier than in the summer. In this context, the justness ('ádil) of Allah was shown. In the summer when the day was very long, the weather was cool. As a result, we did not feel hungry. In the winter, when we needed a lot of food, the fasting time was very short. ${ }^{28}$

Imām $\mathrm{C}$ tried to philosophise about the fasting obligation in the winter and in the summer. As one of the Muslims imams in the Netherlands, Imām $\mathrm{C}$ was doing his best to answer the question of why Muslims are still obliged to observe fasting Ramadan in the summer.

Mrs F, an ordinary person, illustrates a difference experience of how she observed fasting in Ramadan in summer in the Netherlands. She is an active member of Persatuan Pemuda Muslim se-Eropa (abbr. PPME; Association of Muslim Youth in Europe). She came to this country in 1986 and married a native Dutchman.

In connection with fasting in summer, she said that she felt overexhausted (teler). "I broke the fast around 11.00 p.m., and then I had to

${ }^{27}$ Interview with Imām A, 31 October 2003.

28 Interview with Imām C, 14 November 2003. 
perform the prayer of Maghrib, subsequently the prayer of Ishä'. After that, I tried to avoid sleeping in order to not miss having sahür (meal taken after midnight). Even though I had made serious preparations for fasting, in the afternoon, particularly after 5.00 p.m., my energy was totally drained. With the hot weather up to $30^{\circ}$, my head ached and my stomach felt nauseous. At that time, we tended to become psychologically unstable and Satan came to bother us.

I am really no longer want to fast in Ramadan in the summer in this country. Recalling my experience from the past, it is better for me to save money and observe fasting Ramadan in Indonesia. By doing so, I will get double advantages: firstly, I can visit my parents and secondly, I can observe fasting in Ramadan in pleasant, comfortable condition."29

Mrs F shares the view of Imäm A in connection with the effort required to fast in Ramadan in the winter. According to her, fasting in the winter is virtually not fasting. Sahūr may be able to be regarded as having breakfast. She considers this condition as a sign of God's munificence.

A different way of dealing with the fast of Ramadan in the summer was revealed by Mr. I. He is a diamond trader and deals in exclusive jewellery. He was born in 1948 and he came to the Netherlands in 1975. He told me that in order to avoid the long daytime fasting in the summer in the Netherlands, in 1982 he went home to Indonesia. He said frankly that his reason for going home to his country of origin was merely to seek the easy way out. "God does not want to put us in difficulties, so we should not cause ourselves in pain and suffering. I do not like difficulties. Hence, I try seriously to look for some happiness. As a trader, it was easy for me to look for a chance to go somewhere. I knew that God knew my intention perfectly, He is All-Knowing. He knew my motives behind going trading in Ramadan when it fell in the summer. Lying to people is easy, but lying to God is impossible." 30

Furthermore, Mr. I showed me that one of his friends fasted continuously and consequently (in summer and winter) following the fasting time in Indonesia. "His name is Pak Gumilar." ${ }^{31}$ In the above-

29 Interview with Mrs F, 8 November 2003.

30 Interview with Mr. I, 14 November 2003.

31 I also got this his name from Muhammad Yusuf, the present ambassador of Indonesia in the Netherlands. Imām B, as an imām, confirmed this information. They (Mr. I and Pak Yusuf) ask me to do not miss interviewing this person. Regrettably, I 
mentioned stories, we find many peculiarities of how Muslims manage their fasting in the summer in the Netherlands. One of my respondents, he is a native-Dutch Muslim, says that if fasting Ramadan in the summer causes some difficulties or is harmful, it is wise for Muslims to seek an excuse. Muslims, according to him, cannot harm themselves. ${ }^{32}$

Two of my respondents from Morocco said that they cannot give a religious opinion. They only followed the instruction of the imam in religious matters. They observed fasting in Ramadan for 19 hours in the summer because the imām did so. The imām said that this was an obligation and regulation demanded by Islam that Muslims must bear with. ${ }^{33}$ One of my respondents from Algiers shared opinion with his two brothers from Morocco. He said that we have an imàm and we should obey his instruction in religious matters. Thus, all Muslims should follow the ijtibād from the imam. ${ }^{34}$

\section{The Role of Religious Leader}

The role of 'ulama in guiding Muslims to observe fasting Ramadan when the day is very long or very short is paramount. According to Imām A, in the 1980s when Ramadan fell in the summer, people took turns asking him on how to deal with fasting in that context of time. This shows of how curious Muslims are about this kind of obligation. The other indication of Muslims' curiosity about fasting in the summer is revealed in various letters from some of the Muslim minority in Europe to 'ulama asking their opinion about how to deal with fasting in Europe. ${ }^{35}$ In the same manner as the fatwas issued on this problem, we find various answers from imäms in the Netherlands dealing with this problem. Here I show how some imams play their role in giving solutions to the problem of the umma.

One of the imams in The Hague explained to me how he was becoming a man who must accept responsibility for solving the panic among his umma. He said that Muslim people continuously looked for him for answer in this matter. As an imäm, he gave them two choices,

did not have a chance to talk to this person before I had to finish this article.

32 Interview with Mr. J, 17 November 2003.

33 Interview with Mr. L and Mr. M, 14 November 2003.

34 Interview with Mr. K, 14 and 17 November 2003.

35 Mohsen Khalifa, "Ramadan Fasting in Northern Europe," pp. 9-40. 
namely, they can observe fasting by following fasting time in Mecca and Medina, or they can also fast until Maghrib. He himself followed the second alternative. He said that he did not ask them to fast fully (until sunset), but people who broke fasting before the set time were very limited. Most of his umma observed fasting as usual, until sunset. ${ }^{36}$

Imām B, an imām in the Mosque Al-Hikmah in The Hague, expressed a similar solution but with a different nuance. According to him, fasting is a kind of personal íbada (worship). It is a kind of individual responsibility between men and God. Thus, whether it is performed fully (from dawn till sunset) or breaking fasting before Maghrib in the summer is based on individual consideration and belief.

Imām B was born in 1946. He came to the Netherlands in 1970. Because of his religious knowledge, he then was appointed an imam in the Indonesian mosque The Hague, Al-Hikmah Mosque. In connection with his responsibly in guiding the umma, including in observing fasting in Ramadan, Imām B said to me that he gave them the choice. Every Muslim had a right to decide whether they chose to break fasting before sunset or at sunset. "We were not in the position to prohibit them. However, anyone who has the strength to observe fasting as usual (from dawn till sunset), please follow the usual time. If they felt that they did not have enough strength in the middle of the daytime in fasting, they were recommended to break fasting and made it up sometime in the days ahead. I could not summon up the courage to calculate the fasting time in the Netherlands with that of neighbouring country or Mecca and Medina. I took a careful and safe judgement." ${ }^{37}$

In addition to those statements, Imām B said that God gives the seasons in cycle. Muslims must observe fasting in the summer when the day is very long. Conversely, in the winter, Muslims have to bear fasting only for a short time. This is already fair. Fasting in the winter is a blessing from God that Muslims should enjoy. Thus,

"In the happiness we should say alhamdulillah, and in the difficulties we must not moan and complain. Do not only take the easy way; in the summer following the daytime of Mecca and Medina, while in the winter following local time. God is All-Knowing. The more tired we are worshipping Him, the more reward we are earning. Whatever the

36 Interview with Imām A, 14 November 2003.

37 Interview with Imām B, 14 November 2003. 
conditions, we have to observe fasting. We return the entire problem to our belief." 38

Strong advocates of observing fasting in Ramadan from dawn to sunset comes from Imām C and Imàm D. In Imām C's view, the daytime for fasting in Ramadan in the summer in the Netherlands is not long enough. Many countries have a similar length of daytime as the Netherlands in summer. Hence, he concluded that this obligation could still be borne from dawn till Maghrib. It is not required to calculate fasting time in this country with that of a nearby country or with Mecca and Medina. Moreover, he says seriously:

"Ibāda in Islam has fixed customs and manners. There is no place for any new invention. People cannot change the set regulations. On those who fasted by following fasting time in Mecca and Medina, I had no comment. I have explained this matter too often. Our propagators had done so. However, fasting is based on personal belief. If we are convinced that a certain deed is right and proper, we do it. If they are convinced that what they do is right, that is their right. We did not oppose them."39

Imām D is an imàm of Al-Hijra Mosque in Leiden. He was born in 1953 and he came to the Netherlands in 1994. In connection with the role as imàm, he endorsed Imàm C's view by saying that Muslims in the Netherlands must observe fasting in Ramadan in the summer from dawn till sunset. The length of the daytime is not an excuse to break fasting. However, according to him, people who did not have the physical stamina to observe fully can break their fasting before Maghrib.

God revealed the Holy Qur'an for all human being in every part of this world. The obligation to fast is for all Muslims in the countries where the days are very long or short. There are some fatwās from 'ulama that allow Muslims in the countries where the day is very long to break the fast by following a nearby country or the Middle East, but the optimal opinion is fasting from dawn till sunset. ${ }^{40}$

38 Interview with Imām B, 14 November 2003. A similar opinion is also stated by Imām A.

39 Interview with Imām C, 14 November 2003.

40 Interview with Imām D, 17 November 2003. 


\section{Understanding Religious Commands}

The Qur'an (2:187) says “ “... and eat and drink, until the white streak of dawn appear to you distinct from the blackness of night; then complete your fast till the night appears..." From this verse, many Muslims, including the Muslims in the Netherlands, are convinced that the hours decreed for fasting are from dawn till sunset or Maghrib. Here I cite a record or narrative description from Mr. G on how he comprehends this verse.

Mr. G came to the Netherlands in 1975 . He spent almost all of his Ramadan time in this country. He told me one of his understandings of religious texts relating to the fast of Ramadan. He said that he in fact knows that there are fatwas dealing with fasting in the countries where the days are very short and very long. He knows also that some 'ulama' issued fatwas that Muslims in those countries are called to calculate their fasting time according to a nearby country or Mecca and Medina. However, he decided to adopt the regulation from the Qur'an. "I did not follow fatwas which allow Muslims to break fasting before Maghrib (sunset). The Qur'an states clearly that fasting must be observed from sunrise till sunset. Allah gives an equivalent compensation for the double hardship of fasting in the summer with the easiness or effortlessness of fasting in the winter. Fasting in the winter is like a joke, not a serious fasting. The closer to the peak of winter, the easier and shorter of the daytime for fasting." ${ }^{41}$

Mr. G's understanding of the sacred text tends to scriptural meaning. He believes that everything literally stated in the Holy Book is comfortable for and suitable to human beings. Instead of questioning his understanding of the text, he tries to search some arguments to support the literal meaning of the Qur'anic verses.

Imam C's understanding of the meaning of that verse endorses Mr. G's view. According to him, as long as Muslims can find a distinction between daylight and night, they must observe fasting from dawn till sunset. "The Netherlands is different from polar countries. They have dayless night and nightless day. Hence, Muslims in this country must observe fasting completely. This is my principle." ${ }^{42}$

Mrs F reveals another way of understanding of how Muslims in the Netherlands comprehend the religious command. She does not know of

${ }^{41}$ Interview with Mr. G, 8 November 2003.

42 Interview with Imām C, 14 November 2003. 
any fatwa às dealing with fasting in the countries like the Netherlands. Her religious knowledge is mostly based on what she received in her country of origin, Indonesia. The time for fasting in Indonesia is stable, from around 4.00 in the morning till around 6.00 in the evening. Indonesia is a tropical country. It is placed in a zone bounded by longitudes $92^{\circ}$ and $141^{\circ}$ east and by latitudes $6^{\circ}$ north and $11^{\circ}$ south. The climate is broadly equatorial. The temperatures are high but constant. So that, in Indonesia, the fasting time never be questioned. Like almost all of Indonesian, when she came to the Netherlands, she did not pose any questions about the time of fasting. She puts her understanding of religious commands from Indonesia in the context of her new country.

She told me of how she observed fasting Ramadan in her country of origin, Indonesia. She said that she used to sabür (light meal right before dawn) at around 3.00 in the morning and iftar (a meal right after sunset) at around 6.00 p.m. When she came to the Netherlands, she did not feel at all comfortable about ending her fast before sunset. "I supposed I would be able to complete my fasting till sunset. In fact, I found myself did not strong enough to accomplish fasting till Maghrib in the summer. I knew that harming our body was prohibited in religion, but I was not enjoying breaking the fast before sunset. I did not know that there were some fatwa $\bar{s}$ which allow us to break fasting before sunset when the days are very long. I was questioning why some Islamic scholars in the Netherlands like Imām A did not tell us about those fatwäs?"43

Mr. E who was born in 1937 and came to the Netherlands in 1968 has a similar reason as Mrs F as to why he was fasting from dawn till sunset in the last summer-Ramadan. "At that time (1980s), I had no choice. I transferred my knowledge about fasting from Indonesia to the Netherlands. What I knew from my country of origin is to fast from sunrise (dawn, ed.) till sunset in Ramadan. I obeyed that rule. And I found Muslim people from my country of origin did the same thing as I." ${ }^{44}$

From the point of view of religious expertise, both Mr. E and Mrs F belong to the ordinary people. They knew no other alternative. Hence, their efforts were solely with the intention of being a devout or an obedient "servant of God" ('abd Alläh). In this context, they differed

${ }^{43}$ Interview with Mrs F, 8 November 2003.

${ }^{44}$ Interview with Mr. E, 31 October 2003 and 14 November 2003. 
from Imām A. He was already acquainted with some religious fatwās dealing with fasting in the summer, including the fatw $\bar{a}$ which allows Muslims in a country like the Netherlands to calculate the time of fasting according to a nearby country or Mecca and Medina. The reason of why he chose to do fasting fully from dawn till sunset in the summer is he wanted to be consequent. He observed fasting Ramadan from dawn till sunset effortlessly, only around 8 hours, in the winter or when the days were very short, therefore it was only fair be should fast in Ramadan to the point of exhaustion from dawn till sunset in the reverse season or when the days were very long.

Imām A told me of why he chose fasting until Maghrib in the summer. He said that this custom was brought from home (country of origin, ed.). "We were accustomed to fast from dawn until Maghrib. So that, whatever the reason and whatever the condition, we would not change it. This custom was already embedded to the backbone (ke tulang sumsum, lit. spinal cord, or deep-rooted)." ${ }^{45}$

In addition to the above description, Mrs $\mathrm{F}$ gave me an interesting instance of how she sincerely tried to be a devout Muslim in bearing fasting obligation when in it fell in the summer. She said that she forced herself to fast, but her body was not strong enough to fulfil this obligation as literally mentioned in the Qur'an as she understood. She told me that she once fell sick because of this kind of fasting. To overcome this problem, she paid fidya by giving iftat to the needy as a kind of compensation for the days of fasting that she could not accomplish.

Traditionally, Islamic law books ( $f$ igh) permit relaxations in the certain circumstances, for instance, people who have reached a certain age, sick people for whom there is no hope of recovery, in case of mortal danger, and pregnant or nursing women who fear fasting would be dangerous for them. People who fulfil these conditions are obliged to pay fidya by giving iftatar the needy. Fasting when the day is very long and hot is not literally included in the permission to relax fasting. ${ }^{46}$ In the case of Mrs F, she most likely tried to draw an analogy between fasting in the summer and fasting to a point at which it might endanger life.

${ }^{45}$ Interview with Imām A, 14 November 2003.

46 Sābiq, Fiqh al-Sunnah, pp. 325-9. 


\section{The Daylight and Night Time Activities}

The night time in the summer is very short. For Muslims, some religious activities in Ramadan are traditionally recommended to be done at night. In the daytime, when they have to cope with long-time fasting, they are traditionally recommended to look after their worldly needs. In this context, Muslims activities need to be managed efficiently if they do not want to find themselves in trouble. Mr. H, born in 1955 and came to the Netherlands in 1974, illustrated to me on how he managed his time in the last summer-Ramadan (in 1980s) as follows:

I broke fasting at around 10.45 at night with a sufficient meal. This rite was then followed by performing the Magbrib prayer, listening to a religious speech. Prayer ' $s$ sha' and Tarawih were started at around $12.30 \mathrm{a} . \mathrm{m}$. At around 1.00 a.m., I went home. At that moment, I was too sleepy, but if I slept, it was very difficult to wake up before the time of imsäk at around 3.10 a.m., so I had sabür meal before sleeping. For me sabür was highly necessary to support my energy to work the next day. Even though we had the sahür meal at night, my physical condition would often drop and deteriorate at work. However, fasting is not an excuse for not working. ${ }^{47}$

The stories from the other respondents mostly match Mr. H's experience. The difference is their activities in the day and the time for sleeping. Those who were employed worked as usual. Imam B put the time for sleeping after working. Imām A who had a flexible time for working changed his day for sleeping and his night for working, reading the Qur'an, wirid and so forth.

\section{Fasting in the Summer and the Practice of Wisal}

The Prophet Muhammad sometimes used to fast continuously day and night. However, instead of recommending his followers to follow his example of wisall, he strictly forbade them to do the same thing. To some extent, fasting is an act of hardship and suffering. It was, therefore, necessary to prevent the followers of Islam from indulging in it to excess. When certain Companions asked for the reason, he replied, "I am not like you, for I am provided food and drink (by Allah)." ${ }^{48}$

Fasting in the summer is not the same as the practice of wisal.

${ }^{47}$ Interview with Mr. H, 14 November 2003.

48 Al-Zuhailî, al-Fiqh al-Islāmî, p. 636; "Fasting: History and Objectives" in http://www.jamiat.org.za/ramadhaan/fastingho.html. Accessed 15 June 2003. 
All of my respondents said so. Imàm B, for instance, said that the practice of wisal is a kind of excessive worship. Hence, it is plausible the Prophet prohibited it. Instead of asking his followers to continue fasting throughout the night, the Prophet asked them to iftär in hurry when the time comes and to have sabür meal later. Imàm D states that fasting in Ramadan cannot be compared with the practice of wisall.

"It is totally different. The practice of wisal is fasting without a break. The Prophet prohibited this practice. The same thing is adding fasting time in the winter. In this season, the fasting time is very short. In this case, maybe people want to add one or two hours. It is prohibited. Allah obliges them to fast from dawn till sunset without specifying in a certain season. Islam asks its follower to break fasting hurriedly when the time comes. Breaking fasting later is not recommended, let alone adding fasting time whatever the purposes of it. Allah's order for fasting is already fixed without differentiating the season, summer or winter." ${ }^{49}$

\section{Medical Considerations}

In comparison to other 'ibäda (religious services), the fast of Ramadan has a direct relation to the human body. More obviously, according to some medical considerations, it is dangerous to the body if it is done in the hot summer. ${ }^{50}$ In contrast to these considerations, some Muslims happily observe fasting when the daylight time in a day is around 19 hours as in the Netherlands. They have no problem with the fairness of this if Muslims consider the short daylight time in the winter. Fasting in the winter is only around 8 hours. Thus, God gives the Muslims a cycle-regulated time for observing fasting Ramadan over the course of a lifetime.

Physical condition can be considered as an excuse for breaking fasting. In the eyes of common people, fasting 19 hours in a day is very likely to make the observants suffer from sickness. In contrast to this supposition, my respondents gave firm assurances that this religious obligation did not have a bad effect on their health. One of my respondents, Mr. E, said that it was true that he often suffered from sickness in the fasting time. That sickness, according to him, was not

49 Interview with Imām D, 17 November 2003.

${ }^{50}$ Douglas Jehl, "In Egypt this Winter, Fasting for Faith is a Long Banquet." 
a result of his fasting. He had suffered from that sickness before the fasting month. The only person who told that she fell in sick because of fasting was Mrs F.

Imām $\mathrm{B}$ gave me an explanation about the relation between fasting and physical health. He says as follows, "I have never ever suffered from sickness because of fasting. That is the secret of fasting. Everything depends on its intention. If we observe fasting for the sake of God, hunger has no effect on our body. Of course, this is my personal experience, but I think other people have similar experiences. ${ }^{51} \mathrm{~A}$ similar answer was given by Mr. H. He says that his physical condition was not upset by fasting Ramadan in the summer. "Alhamdulillah, God gave us strength. If we chase after taqwä, we will face no difficulties in bearing fasting." 52

In addition to these explanations, according to Imām A, if we are confronted with physical problems on a certain day of fasting in Ramadan in the summer, we are requested to break fasting. Making up of the missing day is not required to be undertaken in the same season. We can make up the missing day in the winter as well as in the summer.

\section{E. Observing Religious Obligations}

There is a tendency in the circle of Islamic scholars to regard religious obligations as fixed. The qa'idah ușüliyya of al-aslu fi al-ibädah altahrim is used as a way to understand and deal with practices of worship such as fasting in Ramadan. The rules of fasting, both in their generalities and particularities, are regarded as permanent. Thus, there is no room for human intelligence to transform or adjust fasting to cast it in a new form in accordance with natural or environmental conditions. It is true that the command to fast is from God, but the way to observe fasting requires the involvement of human participation. The people who can break the fast, for example, is changing in a different time. In the early generation Muslims, travellers over a long distance $(89 \mathrm{~km})$ were allowed to break fasting. Nowadays, that distance $(89 \mathrm{~km})$ is rarely considered as an 'illah (a cause) for breaking the fasting. The distance mentioned can be undertaken in an hour by plane. The concept of mashaqqa (exhaustion)

\footnotetext{
51 Interview with Imām B, 14 November 2003.

${ }^{52}$ Interview with Mr. H, 14 November 2003.
} 
then was considered as a reason for observing or breaking fasting. The process of accepting the concept of mashaqqa in travelling was a recent phenomenon. Before that, the majority of 'ulama still ignore and even oppose this concept.

The problem of fasting when the day is very long is almost the same as the problem of fasting for traveller. Some "ulama consider the time for fasting is fixed, no human creativity can interfere or be involved in this kind of religious obligation. The different concept of night, such as in the Western Europe, is not an excuse for expressing different opinions on how to observe fasting. When the night is traditionally considered to fall when the darkness begins, this concept is also applied in every place, including the countries near the Poles where the concept of day and night is obscure. What commonly happens is some Islamic scholars give reasons on why Muslims should observe fasting in Ramadan for 19 hours in the summer. According to them, this regulation is fair. Muslims observe fasting in the short days in the winter, conversely, they should observe it in the long days in the summer. There are, according to them, also some wisdom behind this religious command. Even though the day is short in the winter, we need a lot of energy. Hence, we need to eat plenty. In the summer, although the days are long, we need a little energy, so that we do not need to eat a lot.

In contrast to the 'ulama, the ordinary people were usually more realistic in their way of thinking. In order to be a devout Muslim, they readily follow 'ulama. However, in the context of hardship (mashaqqa), they usually use their own rationality. Mrs F paid fidya by giving iftar to the needy of the missing days. She tried to observe fasting from dawn until Maghrib, but if she could not bear it until Maghrib because of the length of the day, she would break the fast and pay the iftar. This practice is uncommon in traditional figh books. This raises the question: "Can someone break fasting because of the length of the day?" Mrs F's problem was not her strength to observe fasting, but the length of the day. If fasting was obligatory in a normal day (around 12 hours), it was very probable people could bear it. It was solely because the length of the day was 19 hours, so that people can not bear it. To sum up, the mashaqqa here is the obligation itself.

A peculiar way of dealing with fasting in the summer in the 
Netherlands was shown by Mr. I and Pak Gumilar. Mr. I preferred to go home to Indonesia in order to avoid fasting in the long day summer in the Netherlands. Pak Gumilar had an individual ijtihad. He followed the Indonesian fasting time although he lives in the Netherlands.

There are some reasons behind people's willingness to observe fasting Ramadan in the summer from dawn until Maghrib (around 19 hours). One of the reasons is the traditional custom which they had had handed down to them from their parents and ancestors. This custom, according to some of them, was already ingrained or had become part and parcel of their lives. They did not feel happy abandoning this deep-rooted custom. They did not feel enjoyment and have a sense of blessing if they broke the fast before sunset. The majority of them are immigrants from Muslim countries, such as Indonesia. In their country of origin, fasting in Ramadan is observed from dawn till sunset without any difficulties. The time for fasting in Muslim countries, such as Indonesia, is stable -i.e. around 14 hours. Thus, the question of time is never brought up. In this context, the reason behind the observing of the fasting time fully in the Netherlands is preserving custom, particularly Indonesian custom.

People often considered that their customs were an inherent part of their religious beliefs. Hence, preserving customs is often regarded as preserving religion itself. Any innovations in connection with custom were regarded as violating religious law. In the context of fasting Ramadan in the summer in the Netherlands, the custom handed down --i.e. the tropics fasting time-- was also considered as the fixed Islamic teaching. It must be applied wherever and whenever. Of course, the validity of this view is significant to be discussed.

Another reason of why some people were willing to observe fasting as long as 19 hours was their understanding of the Quran. The Qur'an (2:187) says “.... and eat and drink, until the white streak of dawn appear to you distinct from the blackness of night; then complete your fast till the night appears..." This verse was understood as a command to observe fasting from dawn until Maghrib. The word layl (night) in this verse was traditionally translated into Maghrib. The concept of night in the polar countries or in the countries near the Poles is different from that in tropical countries where number of hours of day and night does not vary greatly. Hence, the hermeneutical problem of the word "night" 
in this verse must be examined seriously in order to shed light on the discourse of fasting in the places where the day is very long or very short.

\section{F. Conclusion}

Most of the imams in the Netherlands encourage Muslims to observe fasting Ramadan in the summer in the Netherlands for the whole day (around 19 hours). Some of them acknowledged that there were some fatwas dealing with fasting in the summer or winter in the country like the Netherlands. However, fasting from dawn until Maghrib in the summer was considered to be the most correct way. Fasting for 19 hours could not be regarded as wișal. The practice of wișal was prohibited by the Prophet, while fasting in Ramadan from dawn until Maghrib was an obligation on all Muslims. In connection with medical considerations, that fasting in the summer did not harm human body at all, people could break their fast if they felt it would endanger their physical condition.

In the empirical practice, there were many courses of action open to deal with fasting in Ramadan in the Netherlands in the summer. First, a number of Muslims did fast from dawn until sun set in each season in which Ramadan has fallen. They claimed that they felt fine observing a fast for 19 hours in the summer. Second, a number of Muslims fasted from dawn until sunset in each season Ramadan fell, but they admitted that they felt that this obligation was really a burden too heavy to be borne. Third, a number of Muslims preferred to go away from the Netherlands when Ramadan fell in the summer. They looked for places with shorter days in which to observe fasting than in the Netherlands. Fourth, a number of Muslims used the fasting time of another Muslim country or Mecca and Medina. These phenomena reveals that the umma had their own reasons and way in observing fasting Ramadan.

For some Muslims who willingly observed fasting Ramadan in the summer from dawn until Maghrib, there were two reasons. Firstly, the statement of the Qur'an (2:187) which says that fasting must be observed from dawn until night. The traditional meaning of night in this verse was Maghrib. Second, the earlier custom handed-down from their countries of origin was fasting from dawn until Maghrib. This custom was often considered an inherent part of the religious obligation and it was brought to their new country, the Netherlands. People can give some remarks to 
these two reasons. For the first reason, the determination of the meaning of the night (layl) became obscure in the countries near the Poles. Thus, the observation of the hermeneutical problem of the word "night" (layl) will probably shed a new light on the way of observing fasting. For the second reason, the question of the fasting time had never arisen in the tropical countries. This custom was most probably not an inherent part of religion. Thus, a process of ijtihad and investigation of this religious command will probably give a new understanding of the obligation of fasting when the day is very long or very short.

Besides the various ways of observing fasting when the day was very long, there were also some concepts for substituting the missing day of fasting when the day is very long. Giving iftar to the needy is an example. This concept was not stated in the classical figh books. Here, the core problem that must be discerned is not the form of substitution of the failure day of observing fasting, but the common definition of the concept of mashaqqa which is mostly connected to the physical ability of the people who observe fasting. Hence, a question must be raised, "Why did people break the fast?" People broke fasting because of the length of the day. Physically and mentally, they can observe fasting for around 12 hours. Fasting around 19 hours in a day for a month was a hardship and difficult to sustain. In this sense, the obstacle of observing the fast mainly lies in the obligation itself, not in the person who bear fasting. 


\section{BIBLIOGRAPHY}

Abou Sheishaa, Mohamed Ali Mohamed. 'Muslims' Celebration of the Month of Ramadan in the Netherlands," Unpublishedpaper submitted to the Seminar "The Empirical Study of Islam in Contemporary Western Europe," Leiden University, 2001.

Ali, Abdullah Yusuf, The Holy Qur'an, Hertfordshire: Wordsworth Classic of World Literature, 2000.

Badawi, Jamal A., "The Obligatory Fasting in Ramadan," in The Muslim World League Journal, vol. 27, no. 9, 1420/1999.

Berg, C.C. (ed.), "Șawm," in The Encyclopaedia of Islam, WebCDedition, Brill Academic Publishers, 2003.

Bowie, Fiona, The Anthropology of Religion, Oxford: Blackwell, 2001.

Chaillu, Paul B. Du, The Land of Midnight Sun, vol. 1, London, 1981.

Dijkstra, Stephanie, The Holland Handbook: The Indispensable Reference Book for the Expatriate, edition 2002-2003. The Hague: Xpat Media, 2002.

Hashem, Muhammad, "Religious Problems of Muslim Minorities within the Western Context: A Case Study of Jādd al-Haqq 'Alī Jādd alHaq's Printed Fatwas to Muslims in the West," unpublished MA Thesis submitted to Leiden University, 1997

Humphreys, R. Stephen, Islamic History: A Framework for Inquiry, London: I.B. Tauris, 1991.

Ilyas, Mohammad, Astronomy of Islamic Times for the Twenty-first Century, Mansell Publishing Limited, 1989.

----, Astronomy of Islamic Calendar, Kuala Lumpur: A.S. NNoordeen, 1997. al-Jazāirī, Abd al-Rahman, al-Fiqh 'alā al-Madhāhib al-'Arba'a, Cairo: Dār al-Kitāb al-'Arabī, n.d.

Khalifa, Mohsen Abd al-Aty Haredy, "Ramadan Fasting in Northern Europe: A Study of the Fatwa of Sheikh Hasanayn Makhlūf and Other Relevant Fatwas and Issues," unpublished paper submitted to the Seminar "Islam and the West: Their Mutual Relations as Reflected in Fatwa Literature," Leiden University, 2000.

Murata, S. And Chittick, C. W., The Vision of Islam, New York: Paragon 
House, 1994.

Nielsen, Jorgen S., Muslims in Western Europe, Edinburg: Ediburg University Press, 1995.

----, Towards a European Islam, London: Macmillan Press, 1999.

Nonneman, Gerd, et al., Muslim Communities in the New Europe, Ithaca: Ithaca Press, 1996.

Pingree, D. "al-Kamar," in The Encyclopaedia of Islam webCDedition, Brill Academic Publishers, 2003.

Plessner, M. "Ramadan," in The Encyclopaedia of Islam webCDedition, Brill Academic Publishers, 2003.

Qinawī, 'Abd al-Razzāq Muhammad, Fatāwa al-Ṣawm, Cairo: Dar al-Aminn, 1998.

Sābiq, Al-Sayyid, Fiqh al-Sunnah, Juz I. Cairo: Dār al-Fath li al-a'lām al'Arabī, 1997.

Wagtendonk, K., Fasting in The Koran, Leiden: E.J. Brill, 1968.

Wüstenfeld, H.F., and E. Mahler, Vergleichungs-Tabellen zur Muslimischen und Iranischen Zeitrechnung Mit Tafeln zur Umrechnung Orient-Christlicher Ären, Wiesbaden: Franz Steiner Verslag GMBH, 1961.

al-Zuhailī, Wahbah, al-Figh al-Islāmì wa Adillatubū, Juz II, Damascus: Dār al-Fikr, 1996.

\section{Other Sources}

Ali, Syed Akbar, "Observations of Fasting in Nature," in http:/ /www. free-minds.org/articles/science/ramadhan.htm.

Faq on Ramadhan and Islamic Fasting in http://www.islamforall. $\mathrm{com} / \mathrm{ramadhan} /$ faq.htm Council on American-Islamic Relations Washington, D.C. Ramadan Publicity Resource Kit. Accessed 15 June 2003.

"Fasting: History and Objectives" in http://www.jamiat.org.za/ ramadhaan/fastingho.html. Accessed 15 June 2003.

"Fast during Ramadan" in http://www.icgt.org/Pillar3.htm. Accessed 15 June 2003.

Islam online site on the internet: http://www.islam-online.net. 
Jalali, Mir Javid, "Ramadan is a time of fasting and spirituality" in http:// www.irvineworldnews.com/Astories/dec7/ramadan.html. Accessed 15 June 2003.

Jehl, Douglas, "In Egypt This Winter, Fasting for Faith Is a Long Banquet," broadcasted on BICNews 24 January 1998. See in http:/ / www.iol.ie/ afifi/BICNews/Islam/islam33.htm. Accessed 15 June 2003.

Muslims in Scandinavian countries website on the internet: http:/ /www. islam-qa.com.

Moon Sighting website on the internet: http:/ / www. moonsighting.com

Najeeb, Noor, "Ramadan fasting nourishes spirit" in http://www. jsonline.com/lifestyle/jump/dec00/ram04120200.asp. Accessed 15 June 2003.

Praying time for The Hague in 2003. See www.indah.nl. Accessed in 12 November 2003.

Tas, Ron, Nearly as Many Muslims as Calvinists in the Netherlands, in www.cbs.nl/en/publications/articles/webmagazine/2003/1298k. htm. Accessed on 10 November 2003.

"The Star and Crescent," compiled by Al-Islaah Publications from Sources: islamicvoice; islam.about; ameen/crescent, courtesy: www. everymuslim.com. See in http://zikr.org/fast/star.htm. Accessed 15 June 2003.

"Seyaam Ramadan (The Fasting of Ramadan)" in http://www.quranislam.org/167.html. Accessed 15 June 2003.

"Ramadan" in http://www.submission.org/SP/DEC99.html. Accessed 15 June 2003.

"Your Manhaj In Ramadhan", The Muslim Creed October 2001 Vol. 9 No. 10.

Publisher: The Daar of Islamic Heritage. In http://www.quraan.com/ Ramadan/ManhajInRamadan.asp. Accessed 15 June 2003.

\section{Interviews}

Interview with Imām A, 31 October 2003 and 14 November 2003. 
Interview with Mr. E, 31 October 2003 and 14 November 2003.

Interview with Mrs F, 8 November 2003.

Interview with Mr. G, 8 November 2003.

Interview with Imām B, 14 November 2003.

Interview with Imām C, 14 November 2003.

Interview with Mr. H, 14 November 2003.

Interview with Mr. I, 14 November 2003.

Interview with Mr. J, 17 November 2003.

Interview with Imām D, 17 November 2003.

Interview with Mr. K, 14 and 17 November 2003.

Interview with Mr. L, 14 November 2003.

Interview with Mr. M, 14 November 2003. 